\title{
Divestiture, Competition, and Regional Labor Earnings: Evidence from the Telecommunications Industry
}

James Peoples*

\begin{abstract}
Theory suggests that the divesture of a corporate monopoly such as AT\&T could lead to greater earnings variations developing across the now autonomous regional companies. Individual worker information drawn from Current Population Survey files is used to investigate divesture's influence on regional earnings in this industry. This study presents evidence suggesting larger erosion of the union telecommunications earnings advantage in regions where state utility commissions encourage competition. A broader regional earnings effect is found for nonunion telecommunications employees. For instance, the earnings advantage of nonunion workers and managers in this industry declined appreciably across all regions. These findings indicate the differing regional earnings effect of divestiture and competition on the three major groups of telecommunications employees.
\end{abstract}

\section{INTRODUCTION}

Corporate divestiture is a common approach used to address diseconomies that can arise from operating large-scale organizations. While such corporate restructuring may enhance companies' competitive advantage, it definitely influences labor markets by altering the landscape of collective bargaining. Economic theory, however, does not provide a definitive hypothesis on the labor earnings effect of divestiture. Divestiture might lead to wage levels differing across companies because unions representing workers of divested companies face the possibility of negotiating with more firms. These firms are more likely to experience varying abilities to meet union earnings demands and varying abilities to withstand labor strikes following divestiture. Unions, though, can promote wage standardization by adopting a pattern bargaining strategy to set wage levels. Empirical investigation of divestiture's effect on labor earnings, then, is necessary to provide insight on this type of interaction between product and labor markets.

This study examines regional labor earnings in telecommunications following the divestiture of American Telephone and Telegraph (AT\&T), the industry's dominant firm. The regional breakup of a highly organized national monopoly allows a test of regional markets' influence on earnings following divestiture. The switch from national to regional negotiations might enhance regional employers' ability to bargain for labor earnings that more closely resemble area earnings.

*Department of Economics, University of Wisconsin-Milwaukee. The author gratefully acknowledges the advice and comments of Jacqueline Agesa, Wallace Hendricks, Gary Hoover, Ann Schwartz-Miller, and Sharon P. Smith. 
This would represent a departure from predivestiture telecommunications labor earnings outcomes. For instance, previous research focusing on the New York labor market indicates that before divestiture national bargaining in this industry contributed to telecommunications earnings rates in the state that were significantly higher than area market rates (Ehrenberg 1979). Rate regulation that allowed the major New York telephone carrier to pass on high labor costs and entry regulation that severely limited telecommunications competition contributed to the large telecommunications earnings premiums in the state. Following divestiture, the switch to price-cap regulation and the easing of entry restrictions by some state regulators penalized the practice of passing on high labor costs. Research examining divestiture's influence on regional earnings patterns of union workers, however, does not find strong evidence suggesting that telecommunications wages are lower in regions where carriers face price-cap regulation and stepped-up competition (Cappelli and Perry 1986; Keefe and Boroff 1994). Furthermore, these studies find relative uniformity of regional telecommunications wages for union workers following divestiture. Even research comparing telecommunications workers earnings to those of their regional counterparts fails to present strong evidence suggesting that regional competition is associated with lower regional telecommunications premiums (Hendricks 1998).

Past findings suggesting a weak association between regional competition and regional telecommunications premiums comport well with the notion that industry unions successfully implemented pattern bargaining to set a national wage standard for their members. In contrast, labor earnings of nonunion workers are more likely to converge to regional levels following divestiture because they are not part of the collective bargaining process. Yet past studies have not investigated this possibility. This study examines this issue by estimating separate union and nonunion earnings equations for telecommunications workers by region. Last, telecommunications earnings differentials of managers are estimated by region. Making this additional observation is warranted since these employees face a highly competitive labor market and present regional telecommunications carriers with possibly the greatest opportunity to pay earnings that more closely resemble area rates.

\section{REGULATORY REFORM AND THE TELECOMMUNICATIONS LABOR MARKET}

\section{Labor Earnings in a Regulated Environment}

Prior to divestiture, AT\&T faced entry and rate regulation. These industry policies heavily influenced regional labor earnings. Entry regulation reduced the earnings determination role of regional labor markets by promoting the development of a large nationally organized workforce. During this period of restricted entry, the Communications Workers of America and the International Brotherhood of Electrical Workers organized 662,000 and 110,000, respectively, of the Bell System's 1,023,000 employees immediately preceding divestiture (Hendricks and 
Sassalos 1991; Keefe and Boroff 1994). The development of such large national unions enhanced their bargaining advantage by allowing them to impose labor strikes against the entire Bell system. In addition, by negotiating nationally these unions were able to avoid the potential wage influence of regional market conditions. ${ }^{1}$ Evidence of telecommunications unions' bargaining advantage is supported by findings revealing union members in this industry receiving predivestiture earnings 46.8 percent above their union counterparts employed in other industries (Peoples 1990).

The ability of unions to negotiate high wages and avoid regional market effects on wages was further strengthened by the type of rate regulation used by federal and state utility commissions. The form of rate regulation used in this industry was the setting of the return on carrier net investment. The determination of rates was based, in part, by setting a maximum markup on labor costs (Ehrenberg 1979). Theory suggests that such regulation contributes to unions negotiating high earnings because regulated employers do not experience the profit losses of their nonregulated counterparts when accepting union wage demands.

The wage advantage derived from predivestiture regulation is not limited to union workers. Nonunion employers competing in a highly organized industry are likely to match union wages to avoid the possibility of losing employees to their larger union rivals. Paying high nonunion wages also helps these employers avoid the unionization of their workforce. Moreover, using union wages as the industry standard reduces the influence of regional markets on nonunion wages. Past research estimating union wage differentials in this industry supports the notion that nonunion members were beneficiaries of a highly organized workforce prior to divestiture. For instance, Hendricks (1994) reports that, on average, from 1973 to 1983 nonunion telecommunications workers actually received slightly higher earnings than their union counterparts. ${ }^{2}$

Managers also benefited from the presence of a highly organized workforce in telecommunications. Prior to divestiture, AT\&T managers were promoted from within the company, and usually started their career employed in a nonmanagement position (Batt 1996). Since AT\&T's nonmanagement workers received wages far above area rates, the additional compensation associated with promotion to manager could generate an area earnings advantage for this set of workers. In support of this view, evidence on New York telecommunications managers' area earnings finds substantial predivestiture earnings premiums for female managers employed in telecommunications (Ehrenberg 1979). ${ }^{3}$

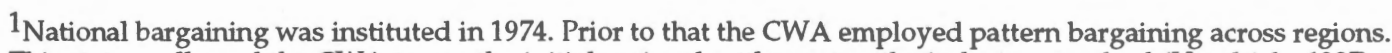
This stategy allowed the CWA to use the initial regional settlement as the industry standard (Hendricks 1987). ${ }^{2}$ Handricks' (1994) findings suggest a union-nonunion log wage differential equaling -0.062 prior to divestiture. ${ }^{3}$ Ehrenberg (1979) finds male managers employed by New York Telephone (NYT) receive earnings resembling that of the non-NYT counterparts.
} 


\section{Divestiture and the Changing Influence of Regional Markets}

The 1984 divestiture of AT\&T radically altered the business environment in telecommunications. Following divestiture, AT\&T was permitted to keep its equipment manufacturing operations and its long-distance service. The Bell system's regional operating companies (RBOCs), however, were divested to create seven autonomous carriers. These regions are depicted in Table 1.4

\section{TABLE 1}

1995 Ranking of Local Competition by State and RBOC

\begin{tabular}{|c|c|c|c|}
\hline $\begin{array}{l}\mathrm{RBOC} \\
\text { (State Coverage) }\end{array}$ & Ranking & $\begin{array}{c}\text { RBOC } \\
\text { (State Coverage) }\end{array}$ & Ranking \\
\hline Pacific Telesis & $2-3$ & Bell Atlantic & $1-3$ \\
\hline Nevada & 2 & New Jersey & 3 \\
\hline \multirow[t]{2}{*}{ California } & 3 & Pennsylvania & 3 \\
\hline & & Delaware & 1 \\
\hline US West & $1-2$ & Maryland & 3 \\
\hline Minnesota & 2 & District of Columbia & 3 \\
\hline Iowa & 2 & Virginia & 2 \\
\hline North Dakota & 1 & West Virginia & 1 \\
\hline South Dakota & 1 & & \\
\hline Nebraska & 2 & NYNEX & $1-4$ \\
\hline Montana & 2 & Maine & 2 \\
\hline Idaho & 1 & New Hampshire & 2 \\
\hline Wyoming & 2 & Vermont & 1 \\
\hline Colorado & 2 & Massachusetts & 3 \\
\hline New Mexico & 2 & Rhode Island & 3 \\
\hline Arizona & 2 & Connecticut & 3 \\
\hline Utah & 2 & New York & 4 \\
\hline Washington & 2 & & \\
\hline \multirow[t]{2}{*}{ Oregon } & 2 & Bell South & $1-2$ \\
\hline & & North Carolina & 2 \\
\hline SBC Communications & $1-2$ & South Carolina & 2 \\
\hline Kansas & 2 & Georgia & 2 \\
\hline Arkansas & 1 & Florida & 2 \\
\hline Oklahoma & 2 & Kentucky & 2 \\
\hline \multirow{2}{*}{ Texas } & 2 & Alabama & 1 \\
\hline & & Mississippi & 1 \\
\hline Ameritech & $2-4$ & Louisiana & 1 \\
\hline Ohio & 2 & & \\
\hline Indiana & 2 & & \\
\hline Illinois & 3 & & \\
\hline Michigan & 3 & & \\
\hline Wisconsin & 4 & & \\
\hline
\end{tabular}

Classification of Competitive Rankings in Local Service:

1 = Minimal competition; 2 = Considering competition; 3 = Competition expected within two years;

4 = Actual competition already exists.

Source: Hendricks (1998).

The application of entry and rate regulation changed following the breakup of the Bell system. At the federal level, the Federal Communications Commission (FCC) relaxed restrictions on entry into the long distance and manufacturing sectors of the telecommunications industry. The FCC also switched from setting maximum rates of return to setting price caps on long distance service. At the state level, regulatory change varied by region. Generally, state Public Utility ${ }^{4}$ The seven regional Bell operating companies are Ameritech, Bell Atlantic, Bell South, NYNEX, Pacific Telesis, SBC Communications, and US West. 
Commissions (PUCs) continued to prohibit entry into RBOCs' local markets. Table 1 reveals that by 1995 significant relaxation of entry restrictions was limited to local transmission services in New York and Wisconsin. These two states operate under the jurisdictions of the NYNEX and Ameritech RBOCs, respectively. The regulatory change enacted by these state PUCs apparently signaled a trend toward easing entry restrictions into NYNEX's and Ameritech's local markets. For instance, Table 1 reveals several other state PUCs in these two regions expected to also take regulatory steps that encourage greater local competition. State PUCs in the Pacific Telesis and Bell Atlantic regions also report movement toward greater competition. In 1991, PUCs in many of these regions also switched from using rate-of-return regulation to using price caps. For instance, the New York State PUC was the first to impose price caps on intrastate transmission, doing so in $1987 . .^{5}$

The changing structure of the telecommunications industry and the differing applications of regulation across states present a serious challenge to telecommunications workers sustaining their regional wage advantage. The ability to receive predivestiture wage premiums, however, might vary by union status.

The potential for telecommunications unions' successfully negotiating uniformly high wages across regions might decline following divestiture since easing entry restrictions facilitated greater competition by nonunion carriers. Evidence presented in panels 1 and 2 of Table 2 suggests that while telecommunications unions no longer control the supply of workers throughout the industry they have maintained their control of the workforce at RBOCs. Columns 1 and 2 in panel 1 reveal an appreciable reduction of the percentage of telecommunications workers in this industry belonging to a union across all RBOC locations. This employment shift, however, did not occur at RBOCs. Columns 1 and 2 in panel 2 indicate unions actually representing an increasing share of the workforce at four of the seven RBOCs. Even the union membership rate decline at the other RBOCs was modest, declining at most 8 percentage points at Bell Atlantic. Only AT\&T experienced significant declines in the percentage of its workforce belonging to a union.

The promotion of regional competition combined with the switch from rate-of-return regulation to price-cap regulation by some state PUCs is more likely to contribute to RBOC carriers resisting pressures to follow a union-negotiated wage pattern. Carriers facing competition experience greater profit losses from paying wages substantially above regional levels. Setting price caps rather than maximum rates of return further restricts the ability of carriers to pass on high union labor costs. Hence, telecommunications unions might face greater difficulty receiving predivestiture wage premiums in more competitive regions such as NYNEX and Ameritech. Eventually, the expectations of greater competition in the Pacific Telesis and Bell Atlantic might encourage these carriers to resist high union wage demands.

${ }^{5}$ Standard and Poor's Industry Outlook, October 1995, rates New York State as one of the most competitive regional telecommunications markets. 
TABLE 2

Unionization Patterns in the Telecommunications Industry

\begin{tabular}{lcc}
\hline Panel 1 & $\begin{array}{c}\text { Percentage of Telecommunications Workforce Belonging to a Union } \\
(2)\end{array}$ \\
RBOC location & $(1)$ & 1996 \\
\hline Ameritech & 1984 & $30 \%$ \\
Bell Atlantic & $62 \%$ & 29 \\
Pacific Telesis & 44 & 30 \\
Bell South & 62 & 27 \\
SBC Communications & 45 & 26 \\
NYNEX & 51 & 40 \\
US West & 62 & 30 \\
\hline
\end{tabular}

Panel 2

RBOC location
Percentage of RBOC Employees Belonging to a Union

1984

$60 \%$

68

61

67

71

63

55

54
(2)

1996

$65 \%$

60

71

66

79

74

54

37

\section{AT\&T}

Sources: 1984 and 1996 Current Population Survey annual outgoing rotation group files were used to calculate the unionization rates in panel 1. Information from the U.S Department of Labor Monthly Labor Review and from Moody's Public Utility Manual, 1985 and 1996, was used to compile the unionization rates at RBOCs reported in panel 2.

Nonunion telecommunications workers across all regions are more likely than their union counterparts to receive wages resembling area rates. The ability of nonunion carriers to pay regional market wages is due, in part, to the declining control of unions over the non-RBOC labor supply. The earnings of managers employed in this industry are also more susceptible to changing local market conditions. Past research reports telecommunications carriers moving away from the practice of promoting managers from the pool of high-wage rank-and-file workers and instead employing managers from outside the company (Batt 1996). The past practice of relying on the internal promotion system reduced the labor earnings influence of local market conditions. Now, carriers need only pay competitive earnings to recruit managers from the external labor market.

\section{DATA SOURCE AND APPROACH USED TO ESTIMATE REGIONAL EARNINGS DIFFERENTIALS}

Information on individual workers is constructed from May Current Population Survey (CPS) files covering the years from 1977 to 1981, and from outgoing rotation groups for each monthly CPS file from 1983 to 1996.6 The 1982 sur-

${ }^{6}$ Even though the CPS files report individual workers information for the years from 1973 to 1976, CPS coding procedure does not assign unique identification to all states before 1977. Thus, the construction of subsample populations is prohibited for each RBOC location.

Sample sizes differing by divestiture regime arise when using the two sets of CPS files. Postdivestiture samples are much larger because the 12-month outgoing rotation groups files are used to construct the population. These files are only available afer 1982. Larger postdivestiture amples imply inflated $t$-statistics compared to the postdivestiture results. Nonetheless, both populations are large enough to provide robust results. A disparity of sample sizes also arises for union and nonunion samples. The smaller sample of union workers reflects their declining share of the workforce since the late 1950s. Despite the small percentage of union members in the workforce, the sample of union workers used in this study is large enough to provide robust results across industries and over time. 
veys are excluded because the union membership question was not asked for this year. The sample selected from these data consists of full-time employees aged 16 to 64 who have information provided on usual weekly earnings, usual hours worked per week and union status. ${ }^{7}$ The advantage of using these files is that they are large enough to construct separate predivestiture and postdivestiture sample populations by RBOC location. CPS files, though, are not large enough to allow examination of annual earnings trends by RBOC. This is a common problem encountered in past research on regional telecommunications earnings (Hendricks 1998). Another shortcoming faced when using CPS files to examine earnings in the telecommunications industry is that this information does not allow analysis that distinguishes earnings paid by AT\&T, non-Bell carriers, and the RBOCs. ${ }^{8}$ Past research, though, does not report appreciable regional variation across CWA contract negotiations with AT\&T and the RBOCs (Cappelli and Perry 1986; Keefe and Boroff 1994). This wage uniformity across carriers does not suggest the potential for large earnings distortions when using industry-level data to examine telecommunications earnings. The inability to distinguish non-Bell and RBOC employees, however, does suggest exercising some caution when interpreting earnings results. ${ }^{9}$ This is especially the case for the postdivestiture nonunion sample, due to the influx of new nonunion carriers.

The sample population selected from CPS files is used to estimate the following log-linear earnings equations for nonmanagement workers and managers, respectively:

$$
\begin{aligned}
\ln \left(\text { earnings }_{\mathrm{j}, \text { rboc, un, ind }}\right)= & \alpha+\beta_{1} \mathrm{wc}+\beta_{2} \text { occ }+\beta_{3} \text { region }+\beta_{4}(\text { Union })+\beta_{5}(\text { Tel }) \\
& +\beta_{6}(\text { Div })+\beta_{7}(\text { Tel } \bullet \text { Div })+\left(\varepsilon_{j, k, \text { rboc, un }}\right), \\
\ln \left(\text { earnings }_{j, \text { rboc, ind }}\right)= & \lambda+\gamma_{1} \mathrm{wc}+\gamma_{2} \text { region }+\gamma_{3}(\text { Union })+\gamma_{4}(\text { Tel })+\gamma_{5}(\text { Div }) \\
+ & \gamma_{6}(\text { Tel } \bullet \text { Div })+\left(v_{j, \text { rboc, ind }}\right),
\end{aligned}
$$

where " $\mathrm{j}$ " indexes individuals, "rboc" indexes individuals' residence in areas serviced by RBOCs, "un" indexes individuals' union status, "ind" indexes two nontelecommunications comparison industry sectors, and "earnings" measures weekly earnings in 1983 dollars. ${ }^{10}$ Thus, the earnings results are based on separate regressions for each of the seven RBOC locations and each of the two industry sector control groups. Manufacturing and service sectors are chosen as the basis of industry sector comparison with telecommunications. The choice of manufacturing follows the approach used in previous research (Hendricks 1998). The choice

\footnotetext{
${ }^{7}$ The selection criteria for managers exclude them from reporting their union status. Individuals employed in this capacity are prohibited from joining a union.

${ }^{8}$ The inability to make this distinction has the greatest wage effect on the New Jersey and New York samples because these are states with high concentrations of AT\&T employees.

${ }^{9}$ Most non-Bell workers who belong to a union are employed by GTE and are represented by the CWA. Labor negotiations between this union and this carrier usually resemble the settlements research with RBOCs.

101987 is chosen as the initial post divestiture observation year because negoiations were first held in the summer of 1986, following the breakup of AT\&T. Thus, 1987 would mark the first year reflecting wage gains that are generated solely from the provisions of the 1986 settlements.
} 
of service sector allows for comparing the earnings of telecommunications workers to the earnings of other workers who also provide a service.

The vector " $\mathrm{Wc}$ " is the set of worker characteristics indicating the individual's marital status, SMSA residency status, race, years of schooling completed, potential years of work experience and the square of this variable, and the natural log of usual hours worked per week.11 The vector "occ" is a set of nonmanagement occupation dummies as classified by the one-digit census coding. Craft worker is chosen as the comparison occupation. ${ }^{12}$ Including the occupation variables addresses the possibility of the workforce composition varying over time and across industries. The vector "region" is a set of regional variables indicating the yearly unemployment and population rates. Including these earnings determinants accounts for differing regional market conditions and addresses earnings distortions caused by time variant effects. The variable "union" depicts the industry unionization rate. Its inclusion addresses the possibility that highly organized industries pay high wages because they employ highly productive workers.

Dummy variables "Tel," "Div," and the interaction term for these variables are of primary concern. The estimated coefficient on the variable "Tel" measures the predivestiture log earnings differential of telecommunications workers over their counterparts in the comparison industry sector. The estimated coefficient on the variable "Div" measures the log earnings change of the nontelecommunications comparison group following divestiture. The estimated coefficient on the interaction term measures the log earnings differential of telecommunications workers following divestiture. Log earnings differentials are converted to percentage differentials by subtracting one from the exponent of these coefficient estimates and multiplying this value by 100 . The accuracy of this conversion can be confirmed by first depicting the wage equation with the functional form (earnings $\left.s_{j, r b o c, u n, i n d}\right)=f(\zeta)$, where $\zeta$ is the set of wage determinants depicted in Equation 1. If telecommunications workers received higher earnings than the comparison group prior to divestiture, the earnings of telecommunications workers are represented by the following:

$$
w_{\text {tel }}=(1+z) f(\zeta),
$$

where " $z$ " is the percentage difference between telecommunications and other workers' earnings. Therefore, the earnings level of telecommunications and other workers can be expressed as follows:

$$
w=(1+z)^{d} f(\zeta)
$$

where " $\mathrm{d}$ " is a dummy variable equaling one if the employee works for the telecommunications industry and zero otherwise. Taking the natural log of both sides of Equation 4 and expressing the equation in a stochastic form gives

\footnotetext{
${ }^{11}$ The inclusion of the square of potential years of work experience addresses the practice of telecommunications companies' substantially improving the pay of new employees during their early years.

${ }^{12}$ The occupation dummy is excluded from the earnings equation for managers since individuals are employed in the same occupation for this sample.
} 
Equation 5, shown below, which is analogous to Equation 1:

$$
\ln \left(\text { earnings }_{\mathrm{j}, \text { rboc, un , ind }}\right)=\mathrm{d}(\ln (1+\mathrm{z}))+\ln (\mathrm{f}(\zeta))+\left(\varepsilon_{\mathrm{j}, \mathrm{k}, \text {,rboc, un }}\right),
$$

where the estimate of $\beta_{5}=(\ln (1+\hat{z})), d=[w c$, occ, region, Union, Div, Tel $\bullet$ Div], and $\ln (f(\zeta))=\alpha+\beta_{1} w C+\beta_{2}$ occ $+\beta_{3}$ region $+\beta_{4}$ Union $+\beta_{6} D i v+\beta_{7}($ Tel $\bullet$ Div $)$. Solving for the predivestiture estimate of the earnings differential between telecommunications predivestiture workers and other workers reveals that $\hat{z}=\exp \left(\beta_{5}\right)=1$. The general form of this equation is also used to convert log earnings differentials to percentage differentials for the estimated coefficients on "Tel" and "Div•Tel."

\section{FINDINGS ON REGIONAL EARNINGS DIFFERENTIALS}

Earnings results derived from estimating Equations 1 and 2 are presented in Tables 3, 4, and 5. The predivestiture telecommunications log earnings differentials for each RBOC are reported in columns 1 and 2. Columns 3 and 4 contain the postdivestiture log earnings differentials and columns 5 and 6 contain the change of the telecommunications differentials following divestiture.

Findings on union earnings are presented in Table 3 . The predivestiture findings in columns 1 and 2 are consistent with the results from past research on telecommunications premiums (Hendricks 1998). Union telecommunications workers received statistically significantly higher earnings than their counterparts in the manufacturing and service sectors. The telecommunications earnings advantage for union workers is larger when service sector is the comparison group. For instance, when compared to workers in the service sector, the earnings advantage of telecommunications workers ranges from a low of 18.41 percent for the Pacific Telesis region to a high of 43.18 percent for the Bell South region. In contrast, the telecommunications workers' earnings advantage over manufacturing workers varies from a low of only 7.46 percent for the US West region to a high of 27.38 percent in the NYNEX region.

The postdivestiture union findings for telecommunications and manufacturing workers modestly support the view that divestiture encourages employers in competitive markets to pay labor earnings that approach area rates. Only the earnings of union telecommunications workers in the competitive NYNEX market show any appreciable convergence to area rates received by their counterparts in manufacturing. In contrast, union telecommunications workers received relatively larger postdivestiture premiums in the US West and Bell South regions. These are regions where reportedly PUCs did not encourage competition.

Using the service sector as the comparison group presents stronger evidence of lower union telecommunications premiums in regions where state PUCs encourage competition. For instance, three of the four largest declines occur in regions where state PUCs allow or are expecting to allow greater competition. Bell South is the only region outside the group of four where the union telecommunications premium declined significantly. Pacific Telesis is the only region belonging to the group of four experiencing a relatively small erosion of the union - 
telecommunications premium. Nonetheless, union telecommunications workers employed in the Pacific Telesis region received the smallest postdivestiture premiums.

\section{TABLE 3}

Union Workers' Log Earnings Results When Using Pooled Data ${ }^{a}$ (Separate Earnings Advantage Results for Telecommunications Workers over their Counterparts in Manufacturing and Service Sector Industries)

\begin{tabular}{|c|c|c|c|c|c|c|}
\hline$\overline{R B O C}$ & \multicolumn{2}{|c|}{$\begin{array}{c}\text { Predivestiture } \\
\text { Telecom. Premium } \\
\beta_{5}\end{array}$} & \multicolumn{2}{|c|}{$\begin{array}{c}\text { Postdivestiture }{ }^{b} \\
\text { Telecom. Premium } \\
\left(\beta_{5}-\beta_{7}\right)\end{array}$} & \multicolumn{2}{|c|}{$\begin{array}{c}\text { Change in } \\
\text { Telecom. Premiums } \\
\beta_{7}\end{array}$} \\
\hline Ameritech & $\begin{array}{l}0.0837 \\
(4.833)^{\mathrm{c}} \\
{[4,601]^{\mathrm{d}}}\end{array}$ & $\begin{array}{c}0.277 \\
(13.114) \\
{[4,995]}\end{array}$ & $\begin{array}{l}0.0857 \\
(2.980) \\
{[4,601]}\end{array}$ & $\begin{array}{l}0.207 \\
(8.997) \\
{[4,995]}\end{array}$ & $\begin{array}{l}0.020 \\
(0.947) \\
{[4,601]}\end{array}$ & $\begin{array}{l}-0.070 \\
(-2.968) \\
{[4,995]}\end{array}$ \\
\hline Bell Atlantic & $\begin{array}{c}0.181 \\
(10.170) \\
{[3,175]}\end{array}$ & $\begin{array}{c}0.261 \\
(12.378) \\
{[4,952]}\end{array}$ & $\begin{array}{c}0.157 \\
(4.300) \\
{[3,175]}\end{array}$ & $\begin{array}{c}0.187 \\
(6.458) \\
{[4,952]}\end{array}$ & $\begin{array}{c}-0.024 \\
(-1.084) \\
{[3,175]}\end{array}$ & $\begin{array}{c}-0.079 \\
(3.355) \\
{[4,952]}\end{array}$ \\
\hline Pacific Telesis & $\begin{array}{l}0.115 \\
(4.622) \\
{[1,826]}\end{array}$ & $\begin{array}{c}0.169 \\
(7.608) \\
{[3,222]}\end{array}$ & $\begin{array}{c}0.138 \\
(1.350) \\
{[1,826]}\end{array}$ & $\begin{array}{c}0.127 \\
(2.586) \\
{[3,222]}\end{array}$ & $\begin{array}{c}0.023 \\
(0.718) \\
{[1,826]}\end{array}$ & $\begin{array}{l}-0.042 \\
(-1.607) \\
{[3,222]}\end{array}$ \\
\hline Bell South & $\begin{array}{c}0.123 \\
(5.490) \\
{[2,526]}\end{array}$ & $\begin{array}{c}0.359 \\
(14.338) \\
{[3,169]}\end{array}$ & $\begin{array}{c}0.164 \\
(3.504) \\
{[2,526]}\end{array}$ & $\begin{array}{c}0.266 \\
(6.730) \\
{[3,169]}\end{array}$ & $\begin{array}{c}0.041 \\
(1.522) \\
{[2,526]}\end{array}$ & $\begin{array}{c}-0.093 \\
(-3.741) \\
{[3,169]}\end{array}$ \\
\hline $\begin{array}{l}\text { SBC } \\
\text { Communications }\end{array}$ & $\begin{array}{c}0.105 \\
(4.410) \\
{[1,654]}\end{array}$ & $\begin{array}{c}0.333 \\
(9.944) \\
{[1,922]}\end{array}$ & $\begin{array}{c}0.088 \\
(2.414) \\
{[1,654]}\end{array}$ & $\begin{array}{c}0.304 \\
(5.298) \\
{[1,922]}\end{array}$ & $\begin{array}{c}-0.017 \\
(-1.150) \\
{[1,654]}\end{array}$ & $\begin{array}{c}-0.029 \\
(-0.840) \\
{[1,922]}\end{array}$ \\
\hline NYNEX & $\begin{array}{c}0.242 \\
(13.341) \\
{[3,084]}\end{array}$ & $\begin{array}{c}0.314 \\
(16.386) \\
{[6,272]}\end{array}$ & $\begin{array}{c}0.203 \\
(2.556) \\
{[3,084]}\end{array}$ & $\begin{array}{c}0.266 \\
(4.641) \\
{[6,272]}\end{array}$ & $\begin{array}{c}-0.039 \\
(-1.754) \\
{[3,084]}\end{array}$ & $\begin{array}{c}-0.088 \\
(-4.162) \\
{[6,272]}\end{array}$ \\
\hline US West & $\begin{array}{c}0.072 \\
(3.523) \\
{[2,328]}\end{array}$ & $\begin{array}{l}0.283 \\
(13.044) \\
{[3,874]}\end{array}$ & $\begin{array}{c}0.120 \\
(2.916) \\
{[2,328]}\end{array}$ & $\begin{array}{l}0.2365 \\
(5.872) \\
{[3,874]}\end{array}$ & $\begin{array}{c}0.048 \\
(1.946) \\
{[2,328]}\end{array}$ & $\begin{array}{l}-0.0465 \\
(-2.013) \\
{[3,874]}\end{array}$ \\
\hline
\end{tabular}

aThese earnings results are the estimated coeficients on the telecommunications dummy and the interaction of this variable with the divestiture dummy in Equation 1. Results from the entire earnings equation equation are available from the author upon request.

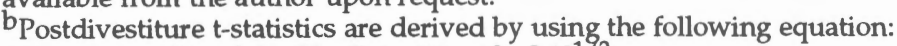

$\mathrm{T}=\left(\beta_{5}-\beta_{7}\right) /\left[\operatorname{Var}\left(\beta_{5}\right)+\operatorname{Var}\left(\beta_{7}\right)-2 \operatorname{Cov}\left(\beta_{5}-\beta_{7}\right)\right]^{1 / 2}$

${ }^{c} \mathrm{~T}$-statistics are presented in parentheses.

$\mathrm{d}_{\text {Sample sizes are presented in brackets. }}$

Telecommunications earnings differentials derived from estimating Equation 1 for the nonunion worker sample are presented in Table 4 . The predivestiture results displayed in column 1 support the view that nonunion telecommunications workers were beneficiaries of a business environment that allowed employers to pass on high wages to customers without the threat of entry from low-cost competitors. These findings show that prior to divestiture nonunion workers in telecommunications received statistically significantly higher earnings than their counterparts in manufacturing and in the service sector. Earnings premiums exceed 19 percent when manufacturing is the comparison group. Even 
larger premiums arise when telecommunications earnings are compared to earnings in the service sector.

\section{TABLE 4}

Nonunion Workers' Log Earnings Results When Using Pooled Data ${ }^{a}$ (Separate Earnings Advantage Results for Telecommunications Workers over their Counterparts in Manufacturing and Service Sector Industries)

\begin{tabular}{|c|c|c|c|c|c|c|}
\hline $\mathrm{RBOC}$ & \multicolumn{2}{|c|}{$\begin{array}{c}\text { Predivestiture } \\
\text { Telecom. Premium } \\
\beta_{5}\end{array}$} & \multicolumn{2}{|c|}{$\begin{array}{c}\text { Postdivestitureb } \\
\text { Telecom. Premium } \\
\left(\beta_{5}-\beta_{7}\right)\end{array}$} & \multicolumn{2}{|c|}{$\begin{array}{c}\text { Change in } \\
\text { Telecom. Premiums } \\
\beta_{7}\end{array}$} \\
\hline Ameritech & $\begin{array}{c}0.182 \\
(7.732)^{\mathrm{c}} \\
{[9,913]^{\mathrm{d}}}\end{array}$ & $\begin{array}{c}0.406 \\
(15.661) \\
{[23,260]}\end{array}$ & $\begin{array}{c}0.145 \\
(2.387) \\
{[9,913]}\end{array}$ & $\begin{array}{c}0.323 \\
(4.934) \\
{[23,260]}\end{array}$ & $\begin{array}{c}-0.037 \\
(-3.669) \\
{[9,913]}\end{array}$ & $\begin{array}{c}-0.083 \\
(-2.767) \\
{[23,260]}\end{array}$ \\
\hline Bell Atlantic & $\begin{array}{c}0.286 \\
(12.941) \\
{[7,925]}\end{array}$ & $\begin{array}{c}0.465 \\
(18.801) \\
{[25,247]}\end{array}$ & $\begin{array}{c}0.197 \\
(4.240) \\
{[7,925]}\end{array}$ & $\begin{array}{c}0.330 \\
(4.458) \\
{[25,247]}\end{array}$ & $\begin{array}{l}-0.0882 \\
(-3.501) \\
{[7,925]}\end{array}$ & $\begin{array}{l}-0.132 \\
(-4.725) \\
{[25,247]}\end{array}$ \\
\hline Pacific Telesis & $\begin{array}{c}0.217 \\
(7.118) \\
{[5,028]}\end{array}$ & $\begin{array}{c}0.349 \\
(10.425) \\
{[12,762]}\end{array}$ & $\begin{array}{c}0.086 \\
(2.628) \\
{[5,028]}\end{array}$ & $\begin{array}{c}0.181 \\
(2.809) \\
{[12,762]}\end{array}$ & $\begin{array}{c}-0.131 \\
(-3.576) \\
{[5,028]}\end{array}$ & $\begin{array}{c}-0.168 \\
(-4.174) \\
{[12,762]}\end{array}$ \\
\hline Bell South & $\begin{array}{c}0.246 \\
(12.583) \\
{[10,909]}\end{array}$ & $\begin{array}{c}0.429 \\
(21.088) \\
{[30,918]}\end{array}$ & $\begin{array}{c}0.141 \\
(3.580) \\
{[10,909]}\end{array}$ & $\begin{array}{c}0.282 \\
(5.764) \\
{[30,918]}\end{array}$ & $\begin{array}{c}-0.105 \\
(-4.692) \\
{[10,909]}\end{array}$ & $\begin{array}{c}-0.147 \\
(-6.378) \\
{[30,918]}\end{array}$ \\
\hline $\begin{array}{l}\text { SBC } \\
\text { Communications }\end{array}$ & $\begin{array}{c}0.241 \\
(9.324) \\
{[5,420]}\end{array}$ & $\begin{array}{c}0.451 \\
(16.397) \\
{[17,289]}\end{array}$ & $\begin{array}{c}0.130 \\
(1.760) \\
{[5,420]}\end{array}$ & $\begin{array}{c}0.302 \\
(4.868) \\
{[17,289]}\end{array}$ & $\begin{array}{c}-0.084 \\
(-2.781) \\
{[5,420]}\end{array}$ & $\begin{array}{c}-0.149 \\
(-4.740) \\
{[17,289]}\end{array}$ \\
\hline NYNEX & $\begin{array}{c}0.292 \\
(11.815) \\
{[8,810]}\end{array}$ & $\begin{array}{c}0.458 \\
(16.409) \\
{[22,740]}\end{array}$ & $\begin{array}{c}0.147 \\
(5.486) \\
{[8,810]}\end{array}$ & $\begin{array}{c}0.269 \\
(7.622) \\
{[22,740]}\end{array}$ & $\begin{array}{c}-0.145 \\
(-5.058) \\
{[8,810]}\end{array}$ & $\begin{array}{c}-0.189 \\
(-5.869) \\
{[22,740]}\end{array}$ \\
\hline US West & $\begin{array}{l}0.228 \\
(9.972) \\
{[6,204]}\end{array}$ & $\begin{array}{c}0.410 \\
(17.56) \\
{[22,309]}\end{array}$ & $\begin{array}{c}0.142 \\
(2.810) \\
{[6,204]}\end{array}$ & $\begin{array}{c}0.286 \\
(5.703) \\
{[22,309]}\end{array}$ & $\begin{array}{c}-0.086 \\
(-3.216) \\
{[6,204]}\end{array}$ & $\begin{array}{l}-0.124 \\
(-5.567) \\
{[22,309]}\end{array}$ \\
\hline
\end{tabular}

a These earnings results are the estimated coeficients on the telecommunications dummy and the interaction of this variable with the divestiture dummy in Equation 1. Results from the entire earnings equation equation are available from the author upon request.

$\mathrm{b}$ Postdivestiture $\mathrm{t}$-statistics are derived by using the following equation:

$T=\left(\beta_{5}-\beta_{7}\right) /\left[\operatorname{Var}\left(\beta_{5}\right)+\operatorname{Var}\left(\beta_{7}\right)-2 \operatorname{Cov}\left(\beta_{5}-\beta_{7}\right)\right]^{1 / 2}$

${ }_{\mathrm{C}}^{\mathrm{T}}$-statistics are presented in parentheses.

$\mathrm{d}_{\text {Sample sizes are presented in brackets. }}$

Postdivestiture results reveal a statistically significant erosion of nonunion telecommunications workers' earnings advantage following divestiture. The contents of column 5 suggest that nonunion telecommunications workers employed in the NYNEX region experienced the largest premium erosion when manufacturing is used as the comparison sector. Nonunion telecommunications workers employed in the Ameritech region experienced the smallest decline. Earnings premium declines for telecommunications workers employed in the NYNEX and Ameritech regions are 13.59 and 3.63 percent, respectively. Both of these regions include state PUCs that encourage competition. The Ameritech results do not 
reveal a general association of larger erosions of the nonunion telecommunications advantage in the competitive regions. The erosion of telecommunications premiums across the seven regions, though, is consistent with the notion that nonunion carriers were able to pay earnings that more closely resemble area earnings during tremendous entry by these carriers. Nonunion telecommunications earnings differential results derived when using the service sector as the comparison group mirror those for manufacturing workers. Findings in column 6 suggest that nonunion telecommunications workers employed in the NYNEX region experienced the largest premium erosion. The smallest erosion occurs in the region covered by Ameritech.

Earnings differential results from estimating Equation 2 for the managerial sample are presented in Table 5. The predivestiture findings reported in columns 1 and 2 are consistent with the view that managers benefited from working in an industry that promoted workers from the ranks of their highly paid workforce. These findings indicate that before divestiture, managers in telecommunications received statistically significantly higher earnings than their counterparts in manufacturing and in the service sector. When the manufacturing sector is used for comparison, the telecommunications premiums range from a low of 13.42 percent in the Bell Atlantic region to a high of 29.56 percent in the Bell South region. These same two regions pay the lowest and highest premiums, respectively, when workers employed in the service sector are used as the comparison group.

Postdivestiture results show an erosion of telecommunications managers' regional earnings advantage following divestiture. The contents of column 5 indicate that only telecommunications managers employed in the Bell South and Pacific Telesis regions experienced a statistically significant premium erosion when the manufacturing sector is used as the earnings comparison group. Nonetheless, the postdivestiture premium for telecommunications managers is less than 10 percent for four of the seven regions. Furthermore, other than the SBC Communications region, postdivestiture premiums do not exceed 16.76 percent.

The managerial earnings results derived when using the service sector as the comparison group provide some evidence of lower telecommunications premiums in regions where state PUCs encourage competition. For instance, four of the five largest declines occur in regions where state PUCs promote, or are expecting to promote, greater competition. Bell South is the only region outside the group of four where managerial earnings for telecommunications managers decline appreciably.

\section{Difference in Differences Approach}

Thus far this study has relied on results derived from pooling information across industry sectors. However, coefficient estimates are restricted to be the same across industry sectors when pooling data to estimate Equations 1 and 2 . A difference in differences approach addresses the problem of coefficient heterogeneity across industry sectors. Such an approach uses a two-step procedure to 
compute relative earnings changes. Initially, the postdivestiture earnings changes are separately estimated for the sample of telecommunications, manufacturing, and services workers. The difference in these earnings differences between industries is then calculated. While the difference in differences approach is less restrictive than using pooled data to estimate changing telecommunications earnings differentials, it does not allow statistical significance testing of earnings changes across industry. The difference in differences results do reveal the magnitude of the relative earnings changes.

\section{TABLE 5}

Managerial Log Earnings Results When Using Pooled Data ${ }^{a}$ (Separate Earnings Advantage Results for Telecommunications Managers over their Counterparts in Manufacturing and Service Sector Industries)

\begin{tabular}{|c|c|c|c|c|c|c|}
\hline$\overline{\mathrm{RBOC}}$ & \multicolumn{2}{|c|}{$\begin{array}{c}\text { Predivestiture } \\
\text { Telecom. Premium } \\
\beta_{5}\end{array}$} & \multicolumn{2}{|c|}{$\begin{array}{l}\text { Postdivestiture }^{b} \\
\text { Telecom. Premium } \\
\left(\beta_{5}-\beta_{7}\right)\end{array}$} & \multicolumn{2}{|c|}{$\begin{array}{c}\text { Change in } \\
\text { Telecom. Premiums } \\
\beta_{7}\end{array}$} \\
\hline Ameritech & $\begin{array}{c}0.167 \\
(3.033)^{\mathrm{c}} \\
{[2,567]^{\mathrm{d}}}\end{array}$ & $\begin{array}{l}0.356 \\
(6.162) \\
{[5,772]}\end{array}$ & $\begin{array}{c}0.092 \\
(0.819) \\
{[2,567]}\end{array}$ & $\begin{array}{l}0.2574 \\
(2.184) \\
{[5,772]}\end{array}$ & $\begin{array}{l}-0.075 \\
(-1.236) \\
{[2,567]}\end{array}$ & $\begin{array}{l}-0.0986 \\
(-1.563) \\
{[5,772]}\end{array}$ \\
\hline Bell Atlantic & $\begin{array}{c}0.126 \\
(2.641) \\
{[2,314]}\end{array}$ & $\begin{array}{c}0.351 \\
(7.616) \\
{[6,459]}\end{array}$ & $\begin{array}{l}0.1121 \\
(1.139) \\
{[2,314]}\end{array}$ & $\begin{array}{c}0.230 \\
(2.45) \\
{[6,459]}\end{array}$ & $\begin{array}{l}-0.0139 \\
(-0.262) \\
{[2,314]}\end{array}$ & $\begin{array}{c}-0.121 \\
(-2.409) \\
{[6,459]}\end{array}$ \\
\hline Pacific Telesis & $\begin{array}{c}0.169 \\
(3.034) \\
{[1,358]}\end{array}$ & $\begin{array}{l}0.387 \\
(5.539) \\
{[3,779]}\end{array}$ & $\begin{array}{c}0.059 \\
(0.505) \\
{[1,358]}\end{array}$ & $\begin{array}{l}0.228 \\
(1.57) \\
{[3,779]}\end{array}$ & $\begin{array}{c}-0.110 \\
(-1.686) \\
{[1,358]}\end{array}$ & $\begin{array}{c}-0.159 \\
(-1.934) \\
{[3,779]}\end{array}$ \\
\hline Bell South & $\begin{array}{c}0.259 \\
(4.984) \\
{[2,071]}\end{array}$ & $\begin{array}{c}0.437 \\
(8.916) \\
{[6,321]}\end{array}$ & $\begin{array}{c}0.095 \\
(0.886) \\
{[2,071]}\end{array}$ & $\begin{array}{c}0.270 \\
(2.678) \\
{[6,321]}\end{array}$ & $\begin{array}{c}-0.164 \\
(-2.802) \\
{[2,071]}\end{array}$ & $\begin{array}{c}-0.167 \\
(-3.045) \\
{[6,321]}\end{array}$ \\
\hline $\begin{array}{l}\text { SBC } \\
\text { Communications }\end{array}$ & $\begin{array}{c}0.205 \\
(3.204) \\
{[1,292]}\end{array}$ & $\begin{array}{c}0.415 \\
(6.034) \\
{[3,849]}\end{array}$ & $\begin{array}{c}0.201 \\
(1.535) \\
{[1,292]}\end{array}$ & $\begin{array}{l}0.352 \\
(2.511) \\
{[3,849]}\end{array}$ & $\begin{array}{c}-0.004 \\
(-0.063) \\
{[1,292]}\end{array}$ & $\begin{array}{l}-0.063 \\
(-0.851) \\
{[3,849]}\end{array}$ \\
\hline NYNEX & $\begin{array}{c}0.135 \\
(2.477) \\
{[2,373]}\end{array}$ & $\begin{array}{c}0.364 \\
(6.205) \\
{[6,408]}\end{array}$ & $\begin{array}{c}0.094 \\
(0.842) \\
{[2,375]}\end{array}$ & $\begin{array}{l}0.236 \\
(1.967) \\
{[6,408]}\end{array}$ & $\begin{array}{c}-0.041 \\
(-0.679) \\
{[2,375]}\end{array}$ & $\begin{array}{c}-0.128 \\
(-1.980) \\
{[6,408]}\end{array}$ \\
\hline US West & $\begin{array}{c}0.169 \\
(3.197) \\
{[1,638]}\end{array}$ & $\begin{array}{c}0.359 \\
(7.338) \\
{[5,286]}\end{array}$ & $\begin{array}{c}0.155 \\
(1.418) \\
{[1,638]}\end{array}$ & $\begin{array}{c}0.311 \\
(3.070) \\
{[5,286]}\end{array}$ & $\begin{array}{c}-0.014 \\
(-0.233) \\
{[1,638]}\end{array}$ & $\begin{array}{c}-0.048 \\
(-0.866) \\
{[5,286]}\end{array}$ \\
\hline
\end{tabular}

a These earnings results are the estimated coeficients on the telecommunications dummy and the interaction of this variable with the divestiture dummy in Equation 1. Results from the entire earnings equation equation are available from the author upon request.

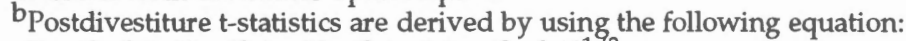

$\mathrm{T}=\left(\beta_{5}-\beta_{7}\right) /\left[\operatorname{Var}\left(\beta_{5}\right)+\operatorname{Var}\left(\beta_{7}\right)-2 \operatorname{Cov}\left(\beta_{5}-\beta_{7}\right)\right]^{1 / 2}$

$\mathrm{c}_{\mathrm{T} \text {-statistics are presented in parentheses. }}$

d Sample sizes are presented in brackets.

Findings on union earnings are presented in Table 6. The results in column 1 suggest that earnings for union members in the telecommunications industry decline slightly across all regions other than NYNEX. The findings for the NYNEX region, though, do not suggest any marked earnings change following divestiture. 
The negligible earnings change in the NYNEX region helps explain the small variation of postdivestiture changes across the seven regions. For instance, the range of regional postdivestiture earnings changes is a low of 0.1 percent at NYNEX to a high of 4.6 percent at US West and Bell Atlantic. The lack of substantial regional earnings variation is consistent with the notion that union members were able to avoid a strong regional earnings influence when telecommunications unions switched to pattern bargaining.

TABLE 6

Difference in Differences Results ${ }^{a}$ (Union Workers Sample)

\begin{tabular}{|c|c|c|c|c|c|}
\hline \multirow[b]{2}{*}{ RBOC } & \multicolumn{3}{|c|}{ Change in Worker Log Earnings } & \multicolumn{2}{|c|}{$\begin{array}{c}\text { Difference in the Change of } \\
\text { Telecom. and Other Workers' } \\
\text { Log Earnings }\end{array}$} \\
\hline & $\begin{array}{l}\text { (Telecom.) } \\
\text { (1) }\end{array}$ & $\begin{array}{c}\text { (Manuf.) } \\
(2)\end{array}$ & $\begin{array}{c}\text { (Service) } \\
(3)\end{array}$ & $\begin{array}{l}\text { (Manuf.) } \\
(4) \\
(1)-(2)\end{array}$ & $\begin{array}{l}\text { (Service) } \\
(5) \\
(1)-(3)\end{array}$ \\
\hline Ameritech & $\begin{array}{c}-0.035 \\
(-1.996)^{\mathrm{b}} \\
{[1,396]^{\mathrm{c}}}\end{array}$ & $\begin{array}{c}-0.049 \\
(-4.352) \\
{[3,204]}\end{array}$ & $\begin{array}{c}0.034 \\
(2.504) \\
{[3,594]}\end{array}$ & 0.014 & -0.069 \\
\hline Bell Atlantic & $\begin{array}{c}-0.047 \\
(-2.845) \\
{[1,413]}\end{array}$ & $\begin{array}{c}-0.004 \\
(-0.238) \\
{[1,761]}\end{array}$ & $\begin{array}{c}0.041 \\
(3.061) \\
{[3,538]}\end{array}$ & -0.043 & -0.088 \\
\hline Pacific Telesis & $\begin{array}{c}-0.023 \\
(-1.468) \\
{[1,004]}\end{array}$ & $\begin{array}{c}-0.021 \\
(-0.715) \\
{[821]}\end{array}$ & $\begin{array}{c}0.032 \\
(1.955) \\
{[2,217]}\end{array}$ & -0.002 & -0.055 \\
\hline Bell South & $\begin{array}{c}-0.011 \\
(-0.627) \\
{[1,386]}\end{array}$ & $\begin{array}{c}-0.055 \\
(-2.594) \\
{[1,139]}\end{array}$ & $\begin{array}{c}0.053 \\
(3.001) \\
{[1,782]}\end{array}$ & 0.044 & -0.064 \\
\hline $\begin{array}{l}\text { SBC } \\
\text { Communications }\end{array}$ & $\begin{array}{c}-0.044 \\
(-2.202) \\
{[921]}\end{array}$ & $\begin{array}{c}-0.022 \\
(-0.928) \\
{[732]}\end{array}$ & $\begin{array}{c}-0.023 \\
(-0.783) \\
{[1,000]}\end{array}$ & -0.022 & -0.021 \\
\hline NYNEX & $\begin{array}{c}0.001 \\
(0.012) \\
{[1,661]}\end{array}$ & $\begin{array}{c}0.039 \\
(2.334) \\
{[1,432]}\end{array}$ & $\begin{array}{c}0.074 \\
(6.304) \\
{[4,620]}\end{array}$ & -0.038 & -0.073 \\
\hline US West & $\begin{array}{c}-0.047 \\
(-3.298) \\
{[1,454]}\end{array}$ & $\begin{array}{c}-0.077 \\
(-3.324) \\
{[873]}\end{array}$ & $\begin{array}{c}-0.031 \\
(-1.849) \\
{[2,419]}\end{array}$ & 0.030 & -0.016 \\
\hline
\end{tabular}

${ }^{\text {a }}$ The earnings results in columns 1,2, and 3 are the estimated coefficients on the divestiture dummy when separately estimating earnings equations for each industry sample. The results in columns 4 and 5 are the difference of the estimated coefficients in columns 1 and 2 and the difference of the estimated coefficients in columns 1 and 3 , respectively. Results from estimating the complete set of earnings equations are available from the author upon request.

$\mathrm{b}_{\mathrm{T}}$-statistics are presented in parentheses. The estimation of separate earnings equations by industry sample prohibits the calculation of t-statistics for columns 4 and 5 .

'Sample sizes are presented in brackets.

The results in column 2 suggest that the regional earnings pattern for the manufacturing sample is similar to that found for union members in telecommunications. As was the case for workers in telecommunications, earnings of union 
workers in manufacturing declined across all regions excluding NYNEX. The similarity between the manufacturing and telecommunications earnings patterns does not necessarily contradict this study's findings of a lack of appreciable regional differences for postdivestiture telecommunication earnings changes. Rather, the regional variation of telecommunications earnings changes that does exist possibly depicts telecommunications earnings changes more closely following the regional market patterns of the manufacturing sector after divestiture.

The results in column 3 suggest that the union earnings pattern in the service sector does not resemble that found in telecommunications and manufacturing. Service sector findings for union workers are indicative of the pressures to pay higher earnings in a high-growth sector of the economy. For instance, only union service sector workers employed in regions covered by SBC Communications and US West experienced earnings declines following divestiture. These declines were statistically significant only for the US West region. In contrast, earnings increases were statistically significant across all of the other five regions.

Difference in differences results derived from comparing union earnings patterns are reported in columns 4 and 5 . These earnings results are consistent with the findings from estimating Equation 1. For instance, when manufacturing is the comparison sector, union earnings patterns in the NYNEX and Bell Atlantic regions depict the largest telecommunications earnings convergence toward area rates. These two regions include states where competition is not discouraged by PUCs. Earnings patterns in the US West and Bell South regions depict the largest telecommunications divergence. These divergences occur in regions where telecommunications competition has not been encouraged. 13 The finding for union telecommunications workers and their counterparts in the service sector reveals an earnings convergence across all seven regions. Four of the largest five convergences occur in regions where PUCs promote or expect to promote competition. 14

Findings on the earnings changes of nonunion workers are presented in Table 7. Results in column 1 suggest that earnings for nonunion telecommunications workers fell significantly across all regions. These declines are much larger than those found for union workers. For instance, the smallest regional earnings decline for nonunion telecommunications workers is 5.5 percent in the Bell Atlantic region. The largest regional decline for union telecommunications workers is only 4.6 percent. The relatively larger declines for nonunion telecommunications workers comport well with the view that increased entry of nonunion competitors weakens the wage influence of unions over the industry workforce.

\footnotetext{
${ }^{13}$ Estimates of earnings equations that replace the divestiture dummy with yearly time dummies reveal the postdivestiture earnings trend for union workers in telecommunications and in manufacturing. These findings indicate that a relatively longer period of declining telecommunications earnings explain the convergence of earnings in the Bell Atlantic region. The length of earnings declines in the NYNEX region is similiar for both sets of workers. Larger annual declines, however, explain the convergence of telecommunications earnings in the NYNEX region. In contrast, a relatively longer period of declining earnings in manufacturing explains the divergence of telecommunications earnings in the regions covered by US West and Bell South. Complete results on annual earnings are available from the author on request.

${ }^{14}$ Results from estimating earnings equations that include yearly dummies suggest that a relatively shorter period of declining earnings for workers in the service sector explains the convergence of telecommunications earnings across all regions. Complete results on annual earnings are available from the author on request.
} 
Apparently, this general reduction of regional nonunion earnings is unique to telecommunications. Results for nonunion workers employed in manufacturing show only four regions experiencing earnings declines while three experienced increases. Furthermore, regional earnings declines in manufacturing are much smaller than those found for telecommunications. Results for nonunion workers in the service sector reveal that earnings increased across all regions excluding US West. The absence of large regional earnings declines for nonunion workers employed in the nontelecommunications comparison sectors explains the nontrivial convergence of telecommunications earnings reported in columns 4 and 5 .

TABLE 7

Difference in Differences Resultsa

(Nonunion Workers Sample)

\begin{tabular}{|c|c|c|c|c|c|}
\hline \multirow[b]{2}{*}{ RBOC } & \multicolumn{3}{|c|}{ Change in Worker Log Earnings } & \multicolumn{2}{|c|}{$\begin{array}{l}\text { Difference in the Change of } \\
\text { Telecom. and Other Workers } \\
\text { Log Earnings }\end{array}$} \\
\hline & $\begin{array}{c}\text { (Telecom.) } \\
\text { (1) }\end{array}$ & $\begin{array}{l}\text { (Manuf.) } \\
(2)\end{array}$ & $\begin{array}{c}\text { (Service) } \\
(3)\end{array}$ & $\begin{array}{c}\text { (Manuf.) } \\
(4) \\
(1)-(2)\end{array}$ & $\begin{array}{c}\text { (Service) } \\
(5) \\
(1)-(3)\end{array}$ \\
\hline Ameritech & $\begin{array}{c}-0.068 \\
(-2.792) \mathrm{b} \\
{[1,002] \mathrm{c}}\end{array}$ & $\begin{array}{c}-0.031 \\
(-3.636) \\
{[8,910]}\end{array}$ & $\begin{array}{c}0.026 \\
(4.105) \\
{[22,259]}\end{array}$ & -0.037 & -0.094 \\
\hline Bell Atlantic & $\begin{array}{c}-0.057 \\
(-2.307) \\
{[1,472]}\end{array}$ & $\begin{array}{c}0.012 \\
(1.215) \\
{[4,288]}\end{array}$ & $\begin{array}{c}0.069 \\
(11.019) \\
{[23,774]}\end{array}$ & -0.045 & -0.126 \\
\hline Pacific Telesis & $\begin{array}{c}-0.159 \\
(-5.147) \\
{[739]}\end{array}$ & $\begin{array}{c}-0.033 \\
(-2.410) \\
{[4,288]}\end{array}$ & $\begin{array}{c}0.014 \\
(1.410) \\
{[12,022]}\end{array}$ & -0.126 & -0.173 \\
\hline Bell South & $\begin{array}{c}-0.092 \\
(-4.385) \\
{[1,788]}\end{array}$ & $\begin{array}{c}0.011 \\
(1.286) \\
{[9,136]}\end{array}$ & $\begin{array}{c}0.055 \\
(10.302) \\
{[29,115]}\end{array}$ & -0.103 & -0.147 \\
\hline $\begin{array}{l}\text { SBC } \\
\text { Communications }\end{array}$ & $\begin{array}{c}-0.159 \\
(-5.828) \\
{[1,003]}\end{array}$ & $\begin{array}{c}-0.054 \\
(-4.532) \\
{[4,416]}\end{array}$ & $\begin{array}{c}0.014 \\
(1.933) \\
{[16,285]}\end{array}$ & -0.105 & -0.145 \\
\hline NYNEX & $\begin{array}{c}-0.081 \\
(-2.853) \\
{[1,009]}\end{array}$ & $\begin{array}{c}0.033 \\
(3.614) \\
{[7,800]}\end{array}$ & $\begin{array}{c}0.081 \\
(11.733) \\
{[11,733]}\end{array}$ & -0.114 & -0.162 \\
\hline US West & $\begin{array}{c}-0.164 \\
(-7.082) \\
{[1,289]}\end{array}$ & $\begin{array}{c}-0.071 \\
(-5.744) \\
{[4,914]}\end{array}$ & $\begin{array}{l}-0.0396 \\
(-5.742) \\
{[21,019]}\end{array}$ & -0.093 & -0.1244 \\
\hline
\end{tabular}

aThe earnings results in columns 1,2, and 3 are the estimated coefficients on the divestiture dummy when separately estimating earnings equations for each industry sample. The results in columns 4 and 5 are the difference of the estimated coefficients in columns 1 and 2 and the difference of the estimated coefficients in columns 1 and 3 , respectively. Results from estimating the complete set of earnings equations are available from the author upon request.

${ }^{\mathrm{b}} \mathrm{T}$-statistics are presented in parentheses. The estimation of separate earnings equations by industry sample prohibits the calculation of t-statistics for columns 4 and 5 .

cSample sizes are presented in brackets. 
Findings on managerial earnings changes are presented in Table 8 . The results in columns 1, 2, and 3 suggest that the regional earnings pattern in telecommunications does not resemble those for the manufacturing and service sectors. Earnings declines in the Bell South and US West regions represent the only sizeable changes for telecommunications managers. In contrast, managers employed in manufacturing experience statistically significant earnings increases at four regions following divestiture. Managers employed in the service sector received statistically significant earnings increases across all regions excluding US West. Telecommunications managers' inability to receive substantial earnings gains explains the convergence of their earnings toward those in the manufacturing and service sectors.

TABLE 8

Difference in Differences Resultsa (Management Sample)

\begin{tabular}{|c|c|c|c|c|c|}
\hline \multirow[b]{2}{*}{$\mathrm{RBOC}$} & \multicolumn{3}{|c|}{ Change in Managerial Log Earnings } & \multicolumn{2}{|c|}{$\begin{array}{c}\text { Difference in the Change of } \\
\text { Telecom. and Other Managers } \\
\text { Log Earnings }\end{array}$} \\
\hline & $\begin{array}{l}\text { (Telecom.) } \\
(1)\end{array}$ & $\begin{array}{l}\text { (Manuf.) } \\
(2)\end{array}$ & $\begin{array}{l}\text { (Service) } \\
(3)\end{array}$ & $\begin{array}{c}\text { (Manuf.) } \\
(4) \\
(1)-(2)\end{array}$ & $\begin{array}{c}\text { (Service) } \\
(5) \\
(1)-(3)\end{array}$ \\
\hline Ameritech & $\begin{array}{c}-0.047 \\
(-0.786)^{\mathrm{b}} \\
{[394]^{\mathrm{c}}}\end{array}$ & $\begin{array}{c}0.043 \\
(2.123) \\
{[2,172]}\end{array}$ & $\begin{array}{l}0.065 \\
(4.588) \\
{[5,337]}\end{array}$ & -0.090 & -0.112 \\
\hline Bell Atlantic & $\begin{array}{c}0.035 \\
(0.727) \\
{[651]}\end{array}$ & $\begin{array}{c}0.017 \\
(0.705) \\
{[1,662]}\end{array}$ & $\begin{array}{r}0.129 \\
(9.457) \\
{[5,807]}\end{array}$ & 0.018 & -0.094 \\
\hline Pacific Telesis & $\begin{array}{c}-0.043 \\
(-0.912) \\
{[245]}\end{array}$ & $\begin{array}{l}0.062 \\
(2.197) \\
{[1,112]}\end{array}$ & $\begin{array}{c}0.094 \\
(4.491) \\
{[3,533]}\end{array}$ & -0.105 & -0.137 \\
\hline Bell South & $\begin{array}{c}-0.089 \\
(-1.437) \\
{[469]}\end{array}$ & $\begin{array}{c}0.087 \\
(3.480) \\
{[1,601]}\end{array}$ & $\begin{array}{l}0.096 \\
(6.961) \\
{[5,842]}\end{array}$ & -0.176 & -0.185 \\
\hline $\begin{array}{l}\text { SBC } \\
\text { Communications }\end{array}$ & $\begin{array}{c}-0.034 \\
(-0.592) \\
{[325]}\end{array}$ & $\begin{array}{c}-0.010 \\
(-0.329) \\
{[966]}\end{array}$ & $\begin{array}{c}0.034 \\
(2.008) \\
{[3,523]}\end{array}$ & -0.024 & -0.068 \\
\hline NYNEX & $\begin{array}{c}-0.002 \\
(-0.027) \\
{[384]}\end{array}$ & $\begin{array}{l}0.065 \\
(2.950) \\
{[1,988]}\end{array}$ & $\begin{array}{l}0.138 \\
(9.651) \\
{[6,023]}\end{array}$ & -0.067 & -0.140 \\
\hline US West & $\begin{array}{c}-0.067 \\
(-1.493) \\
{[444]}\end{array}$ & $\begin{array}{c}-0.023 \\
(-0.708) \\
{[1,193]}\end{array}$ & $\begin{array}{l}0.000 \\
(0.000) \\
{[4,841]}\end{array}$ & -0.044 & -0.067 \\
\hline
\end{tabular}

a The earnings results in columns 1,2 , and 3 are the estimated coefficients on the divestiture dummy when separately estimating earnings equations for each industry sample. The results in columns 4 and 5 are the difference of the estimated coefficients in columns 1 and 2 and the difference of the estimated coefficients in columns 1 and 3 , respectively. Results from estimating the complete set of earnings equations are available from the author upon request.

${ }^{\mathrm{b}} \mathrm{T}$-statistics are presented in parentheses. The estimation of separate earnings equations by industry sample prohibits the calculation of t-statistics for columns 4 and 5 .

'Sample sizes are presented in brackets. 


\section{CONCLUSION}

Divestiture of the dominant U.S. telecommunications carrier presents a challenge to workers sustaining high area wages because the newly autonomous regional carriers now have greater latitude to set wages. Analysis of the industry labor market indicates that the regional influence of divestiture and competition should vary by union status. Continued union control over the supply of workers at RBOCs enhances the unions' ability to negotiate high area earnings for their members. Telecommunications unions, however, should face greater resistance to their wage demands in regions where PUCs encourage competition with the RBOCs. Nonunion workers and managers are much more susceptible to market pressures to lower labor costs across all regions. Nonunion workers operate primarily in industry sectors facing greater competition. Changes in promotional practices weaken the association between managerial and union earnings patterns.

This study examines the effect of enhanced competition on regional telecommunications premiums. Findings for union workers indicate modest evidence of a declining telecommunications earnings advantage over their counterparts in manufacturing where state PUCs support competition. Such findings are consistent with past research. What are new are this study's union earnings findings when the service sector is the comparison group. There is strong evidence of eroding union telecommunications workers' earnings advantage over their counterparts in the service sector in regions where competition is supported by state regulators. Findings on nonunion workers and managers employed in telecommunications reveal a broader vulnerability to increasing pressures to lower labor costs. They experienced nontrivial erosion of their earnings premiums across all regions. The growing significance of cost savings should only heighten in the near future, given the 1996 Telecommunications Act's focus on encouraging stepped-up competition in this industry. Furthermore, the recent wave of merger activity among telecommunications carriers potentially enhances their ability to take advantage of the provisions in the act by improving their ability to compete successfully in all sectors of the industry. Regional findings from this study indicate that union telecommunications workers are not completely protected from competition's downward pressure on earnings premiums.

\section{REFERENCES}

Batt, R. "From Bureaucracy to Enterprise? The Changing Jobs and Careers of Managers in Telecommunications Services." In P. Osterman (ed.) Broken Ladders and Managerial Careers in the New Economy. Oxford: Oxford University Press, 1996.

Cappelli, P., and C.R. Perry. "Bargaining in Telecommunications After Divestiture." University of Pennsylvania working paper number 628, December 1986. 
Ehrenberg, R.G. The Regulatory Process and Labor Earnings. New York: Academic Press, 1979.

Hendricks, W. "Labor Negotiations with Regional Monopolies: The Telecommunications Industry." In J. Peoples (ed.) Regulatory Reform and Labor Markets. Boston: Kluwer Academic Press, 1998.

. "Deregulation and Labor Earnings." Journal of Labor Research 15 (1994), 207-234.

. "Telecommunications." In D. Lipsky and C. Donn (eds.) Collective Bargaining in American Industry: Contemporary Perspectives and Future Directions. Lexington, MA: Lexington Books, 1987.

Hendricks, W., and S.C. Sassalos. "Labor Employment and Wages." In B.G. Cole (ed.) After the Breakup: Assessing the New Post ATET Divestiture Era. New York: Columbia University Press, 1991.

Keefe, J., and K. Boroff. "Telecommunications Labor-Management Relations After Divestiture." In Paula Voos (ed.) Contemporary Collective Bargaining in the Private Sector. Madison, WI: Industrial Relations Research Association, 1994.

Peoples, J. "Wage Outcomes Following the Divestiture of AT\&T." Information Economics and Policy Journal 4 (1990), 105-126. 
